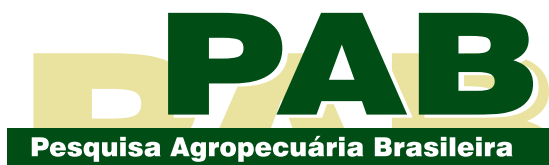

ISSN 1678-3921

Journal homepage: www.embrapa.br/pab

For manuscript submission and journal contents, access: www.scielo.br/pab

Amanda Letícia Pit Nunes ${ }^{(1 凶)}$ (iD,

Glassys Louise de Souza Cortez ${ }^{(1)}$ (iD),

Thadeu Rodrigues Melo(1) (iD,

Alex Figueiredo (1) (iD,

Cassio Alexandre Rolan Wandscheer ${ }^{(2)}$ (D), Jeankleber Bortoluzzi(3) (iD,

George Gardner Brown ${ }^{(4)}$ (iD,

Marie Luise Carolina Bartz ${ }^{(5)}$ (iD,

Ricardo Ralisch ${ }^{(1)}$ (iD and

Maria de Fátima Guimarães ${ }^{(1)}$ (iD

(1) Universidade Estadual de Londrina, Centro de Ciências Agrárias, Departamento de Agronomia, Campus Universitário, Caixa Postal 6.001, CEP 86051-990 Londrina, PR, Brazil. E-mail: amanda.pit@outlook.com, glassyscortez@yahoo.com.br, thadeurodrigues@hotmail.com, alexkdn@hotmail.com,

ralisch@uel.br, mfatima@uel.br

(2) Fundação Parque Tecnológico Itaipu, Avenida Tancredo Neves, no 6.731, Caixa Postal 2.039, CEP 85.867-900 Foz do Iguaçu, PR, Brazil.

E-mail: cassior@pti.org.br

(3) Federação Brasileira de Plantio Direto e Irrigação, Avenida Presidente Tancredo Neves, no 6.731, Parque Tecnológico de Itaipu, Edifício das Águas, $2 .^{\circ}$ andar, sala 201, Caixa postal AC-PTI-2140, CEP 84010 350 Foz do Iguaçu, PR, Brazil.

E-mail: jeankleber_smi@hotmail.com

(4) Embrapa Florestas, Estrada da Ribeira, Km 111, Parque Monte Castelo, CEP 83411-000 Colombo, PR, Brazil.

E-mail: minhocassu@gmail.com

(5) Universidade Positivo, Rua Professor Pedro Viriato Parigot de Souza, № 5.300, CEP 81280-330 Curitiba, PR, Brazil.

E-mail: bartzmarie@gmail.com

$\bowtie$ Corresponding author

Received

February 12, 2019

Accepted

May 05, 2020

How to cite

NUNES, A.L.P.; CORTEZ, G.L. de S.; MELO,

T.R.; FIGUEIREDO, A.; WANDSCHEER,

C.A.R.; BORTOLUZZI, J.; BROWN, G.G.

BARTZ, M.L.C.; RALISCH, R.; GUIMARÃES,

M. de F. Farm systems, soil chemical properties,

and clay dispersion in watershed areas.

Pesquisa Agropecuária Brasileira, v.55,

e01279, 2020. DOI: https://doi.org/10.1590/

S1678-3921.pab2020.v55.01279.

\section{Farm systems, soil chemical properties, and clay dispersion in watershed areas}

\begin{abstract}
The objective of this work was to evaluate the effect of different farm systems on clay dispersion and its relationship with soil chemical properties and the no-tillage system participatory quality index (IQP), in watershed areas in the west of the state of Paraná, Brazil. The farm systems evaluated were: no-tillage; no-tillage with crop succession; no-tillage with soil disturbance; and conventional system. In addition, the farm systems were evaluated for their IQP. Soil samples were collected at $0.0-0.20$ $\mathrm{m}$ soil depth, in 40 agricultural areas and in 6 native forests considered as references. The degree of clay dispersion, total organic carbon, $\mathrm{pH}\left(\mathrm{CaCl}_{2}\right)$, exchangeable potassium $\left(\mathrm{K}^{+}\right)$, available phosphorus $(\mathrm{P})$, exchangeable calcium and magnesium $\left(\mathrm{Ca}^{2+}+\mathrm{Mg}^{2+}\right)$, and potential acidity $\left(\mathrm{H}+\mathrm{Al}^{3+}\right)$ were determined. A linear multiple regression model was fitted by the method of least squares. The averages of clay dispersion degree per watershed were compared at 5\% probability. The farm systems were compared by Scott-Knott's test. Soil chemical properties showed a higher influence on clay dispersion than the different farm systems assessed. The no-tillage system alone showed the highest content of organic carbon, which was similar to those of the native areas. The conventional system and the no-tillage system with soil disturbance showed a lower IQP and a higher degree of clay dispersion than the areas with the no-tillage system alone. The IQP allows distinguishing the conventional system from the no-tillage system.
\end{abstract}

Index terms: conservation system, conventional system, no-tillage system, soil chemical properties, soil tillage.

\section{Sistemas de manejo, atributos químicos do solo e dispersão de argila em áreas de microbacias}

Resumo - O objetivo deste trabalho foi avaliar o efeito de diferentes sistemas de manejo sobre o grau de dispersão de argila e sua relação com os atributos químicos do solo e o índice de qualidade participativo (IQP) do sistema plantio direto, em áreas de microbacias do Oeste do Paraná. Os sistemas de manejo avaliados foram: sistema plantio direto; plantio direto com sucessão de culturas; plantio direto com revolvimento do solo; e sistema convencional. Além disso, os sistemas de manejo foram avaliados quanto ao seu IQP. Amostras de solo foram coletadas a $0,0-0,20 \mathrm{~m}$ de profundidade do solo, em 40 áreas agrícolas e em 6 matas nativas tidas como referências. Foram avaliados grau de dispersão de argila, carbono orgânico total, $\mathrm{pH}$ $\left(\mathrm{em} \mathrm{CaCl}_{2}\right.$ ), potássio trocável $\left(\mathrm{K}^{+}\right)$, fósforo disponível $(\mathrm{P})$, cálcio e magnésio trocáveis $\left(\mathrm{Ca}^{2+}+\mathrm{Mg}^{2+}\right)$, e acidez potencial $\left(\mathrm{H}+\mathrm{Al}^{3+}\right)$. Ajustou-se um modelo de regressão linear múltipla pelo método dos mínimos quadrados. Realizou-se a comparação de médias do grau de dispersão de argila, por microbacia, a 5\% de probabilidade. Os sistemas de manejo foram comparados pelo teste de ScottKnott. Os atributos químicos do solo apresentaram maior influência sobre a 
dispersão da argila do que os diferentes sistemas de manejo avaliados. O sistema plantio direto integral apresentou o maior teor de carbono orgânico, que foi semelhante ao das áreas nativas. $\mathrm{O}$ sistema convencional e o plantio direto com revolvimento do solo apresentaram menor IQP e maiores taxas de dispersão de argila do que as áreas sob sistema plantio direto integral. O IQP permite diferenciar os sistemas de manejo convencional e plantio direto.

Termos para indexação: sistema conservacionista, sistema convencional, sistema plantio direto, atributos químicos do solo, preparo do solo.

\section{Introduction}

The use of the soil and its management change the agricultural productivity and sustainability. The quality of the farm systems and of anthropic actions can be assessed by the alterations caused to soil physical, chemical, and biological properties (Matias et al., 2012; Cardoso et al., 2013). Erosion is the main negative environmental impact from inadequate soil use, which results in particle loss, watercourse silting, and reduction of soil fertility and agricultural productivity (Demarchi \& Zimback, 2014).

Together with other soil properties, waterdispersible clay is used to understand the stability of the soil microstructure and its relationship with erosive processes (Igwe \& Obalum, 2013), since the released particles can clog the pores, reducing the water flows and gases (Chaves et al., 2001; Nguetnkam \& Dultz, 2014). In addition, these particles are easily transported in flowing streams to waterbodies (Demarchi \& Zimback, 2014), favoring their contamination (Martin et al., 2015).

Conservation systems, such as the no-tillage system (NTS), have been adopted as an alternative to ensure soil conservation. In the NTS, the continuous input of organic wastes is essential to the maintenance of the soil structure (Silva et al., 2014) and to increase the stability of the aggregates (Silva et al., 2011). The NTS has as its three main principles the minimum soil disturbance, crop rotation, and permanent soil cover, either by straw or living plants (Nunes et al., 2020). However, it is not always completely implemented, which results in the reduction of its benefits as a conservation practice (Silva et al., 2014).

To monitor the quality of management systems and reduce the degradation risks of the agricultural production systems, the no-tillage system participatory quality index (IQP) was proposed by the Federação Brasileira de Plantio Direto e Irrigação (FEBRAPDP) (Metodologia..., 2011), in partnership with Itaipu Binacional, to predict the potential impacts of future scenarios in a qualitative or demonstrative way (Roloff et al., 2011). In addition, the tool results in the recommendation of improvements for management practices, with the differential feature of the active participation of producers themselves in the monitoring of the NTS quality (Nunes et al., 2020).

The objective of this work was to evaluate the effect of the different farm systems on clay dispersion, and its relationship with soil chemical properties and IQP index in watersheds areas, in the state of Paraná, Brazil.

\section{Materials and Methods}

The study areas are located in the Paraná 3 hydrographic watershed, in the west Paraná mesoregion, between $24^{\circ} 01^{\prime} \mathrm{S}$ and $25^{\circ} 35^{\prime} \mathrm{S}$ and $53^{\circ} 26^{\prime} \mathrm{W}$ and $54^{\circ} 37^{\prime} \mathrm{W}$, at $420 \mathrm{~m}$ altitude, composed by 28 municipalities, in the state of Paraná, Brazil.

The predominant class of soil in the areas is Latossolo Vermelho distrófico (Santos et al., 2013), Ferralsol (FAO, 1988) or Oxisol (Soil Survey Staff, 2014), followed by Ultisol (FAO, 1988). The climate of the region is Cfa (subtropical with hot summers), according to the classification of Köppen-Geiger.

The soil sampling was performed between June and July 2015, in the municipalities of Mercedes, Toledo, Itaipulândia, Santa Helena, Entre Rios do Oeste, and Marechal Cândido Rondon, in the state of Paraná. The areas were grouped according to the municipality: micro watersheds of Sanga Mineira (2 areas); Toledo (7 areas); Buriti (3 areas); Pacuri (3 areas); Facão Torto (4 areas); Arroio Fundo, Ajuricaba, and Curvado (21 areas).

Forty areas with different levels of management quality were sampled, and six native forests (NF) were used as reference, corresponding each NF to each municipality in the cluster (Table 1). The farm management quality was assessed, using the IQP, which is composed of eight indicators (crop rotation intensity, crop rotation diversity, persistence of straw, soil-tillage frequency, correct terracing, soil conservation evaluation, balanced soil fertilization, and producer's commitment (time of adoption of NTS) 
Table 1. History data of the farms: surface (in hectares), years under no-tillage system (t NTS), contour farming (yes or no), soil disturbance (if yes, periodicity), succession of crops, and IQP score.

\begin{tabular}{|c|c|c|c|c|c|c|}
\hline Area & $\begin{array}{c}\text { Surface } \\
\text { (ha) }\end{array}$ & $\begin{array}{l}\text { t NTS } \\
\text { (year) }\end{array}$ & Contour farming & Soil disturbance & Succession of crops & IQP \\
\hline 1 & 15.00 & 19 & Yes & No & Soybean/maize/fallow & 8.0 \\
\hline 2 & 13.44 & 12 & Yes & Each 2 years & Soybean/maize/oat & 7.5 \\
\hline 3 & 15.55 & 22 & Yes & No & Soybean/maize/fallow & 5.3 \\
\hline 4 & 23.39 & 26 & Yes & No & Soybean/maize/oat & 8.3 \\
\hline 5 & 26.23 & 19 & Yes & No & Soybean/maize/fallow & 8.6 \\
\hline 6 & 19.81 & 24 & Yes & No & Soybean/maize/fallow & 8.4 \\
\hline 7 & 75.34 & 21 & Yes & No & Soybean/maize/fallow & 8.6 \\
\hline 8 & 48.51 & 26 & No & No & Soybean/maize/fallow & 7.6 \\
\hline 9 & 33.91 & 20 & No & No & Soybean/maize/wheat & 7.8 \\
\hline 10 & 15.11 & 20 & Yes & Each 6 years & Soybean/maize/oat & 5.6 \\
\hline 11 & 9.71 & 20 & Yes & No & Soybean/maize/fallow & 7.8 \\
\hline 12 & 3.85 & 22 & Yes & No & Soybean/maize/oat & 8.4 \\
\hline 13 & 72.39 & 18 & Yes & No & Soybean/maize/fallow & 5.5 \\
\hline 14 & 4.84 & 22 & Yes & Each 3 years & Soybean/maize/fallow & 8.5 \\
\hline 15 & 195.04 & 18 & Yes & Each 6 years & Soybean/maize/fallow & 7.3 \\
\hline 16 & 26.36 & 15 & No & No & Soybean/soybean/wheat & 3.3 \\
\hline 17 & 10.02 & 12 & Yes & Each 2 years & Soybean/maize/fallow & 6.9 \\
\hline 18 & 0.97 & $\mathrm{CS}^{(1)}$ & Yes & Each 2 years & Cassava/pasture & 4.1 \\
\hline 19 & 54.02 & 19 & Yes & Each 5 years & Soybean/maize/fallow & 6.1 \\
\hline 20 & 6.73 & 24 & Yes & No & Soybean/maize/fallow & 7.8 \\
\hline 21 & 5.56 & 24 & Yes & No & Soybean/maize/fallow & 7.2 \\
\hline 22 & 2.14 & 25 & Yes & No & Soybean/maize/fallow & 5.8 \\
\hline 23 & 38.95 & 15 & Yes & No & Soybean/maize/fallow & 4.4 \\
\hline 24 & 1.10 & 12 & Yes & No & Soybean/maize/fallow & 7.0 \\
\hline 25 & 2.05 & 19 & Yes & Annual & Soybean/maize/oat & 7.1 \\
\hline 26 & 2.12 & $\mathrm{CS}^{(1)}$ & Yes & Each 2 years & Cassava & 5.7 \\
\hline 27 & 16.52 & 19 & Yes & No & Soybean/maize/oat & 6.3 \\
\hline 28 & 5.96 & 14 & Yes & No & Soybean/maize/fallow & 6.6 \\
\hline 29 & 3.62 & $\mathrm{CS}^{(1)}$ & No & Annual & Soybean/maize/fallow & 4.0 \\
\hline 30 & 25.36 & 24 & Yes & No & Soybean/maize/fallow & 8.3 \\
\hline 31 & 14.87 & 24 & Yes & Annual & Soybean/maize/oat & 7.5 \\
\hline 32 & 6.58 & 19 & Yes & Annual & Soybean/maize/oat & 6.8 \\
\hline 33 & 5.28 & 9 & No & No & Soybean/maize/fallow & 6.4 \\
\hline 34 & 4.27 & 7 & Yes & No & Soybean/maize/fallow & 7.0 \\
\hline 35 & 2.03 & $\mathrm{CS}^{(1)}$ & Yes & Annual & Cassava/soybean & 7.4 \\
\hline 36 & 11.92 & 19 & Yes & No & Soybean/maize/fallow & 7.8 \\
\hline 37 & 4.47 & 18 & No & Each 4 years & Soybean/maize/fallow & 7.4 \\
\hline 38 & 8.18 & 12 & Yes & Each 3 years & Soybean/maize/fallow & 5.0 \\
\hline 39 & 20.5 & 24 & Yes & No & Soybean/maize/fallow & 6.3 \\
\hline 40 & 6.13 & 13 & Yes & Each 6 years & Soybean/maize/fallow & 5.4 \\
\hline
\end{tabular}

${ }^{(1)} \mathrm{CS}$, conventional system; IQP, participatory quality index. 
(Table 2). The IQP score was obtained between June and July, 2015, from farmers' questionnaire responses, and from a local visit by the teams of Itaipu Binacional, Parque Tecnológico Itaipu (PTI), and FEBRAPDP, using the method described by FEBRAPDP (Metodologia..., 2011). The farm systems were divided into the following types: no-tillage system (NTS); notillage with crop succession (NT); no-tillage with soil disturbance (NTD); and conventional system (CS). The NTS met the basic assumptions of permanent soil cover, crop rotation, and minimum soil disturbance (Nunes et al., 2020). The other farm systems grouped as the following descriptions. NT was characterized by minimum soil disturbance and succession of crops (only two different crop species in a year). NTD was subjected to soil tillage for the control of soil compaction and weed. CS was characterized by periodic soil disturbance, by means of plowing and harrowing, at the moment of each crop planting.

For the chemical and physical analyses, five points spaced $30 \mathrm{~m}$ apart were sampled in each area, at $0-0.20 \mathrm{~m}$ soil depth, arranged in a transect according to the methodology described by Bartz et al. (2013). The samples were air dried, ground, and sieved to $2 \mathrm{~mm}$. The chemical analyses were performed according to Tedesco et al. (1995). Determinations for $\mathrm{pH}$ in $\mathrm{CaCl}_{2}$, $\mathrm{H}+\mathrm{Al}^{3+}, \mathrm{Ca}^{2+}+\mathrm{Mg}^{2+}, \mathrm{P}, \mathrm{K}^{+}$, and the granulometry and clay dispersed in water were performed according to
Claessen (1997); and total organic carbon (TOC) was determined according to Walkley \& Black (1934).

The granulometry determination was carried out by the pipette method, with slow stir, using sodium hydroxide solution (1 $\mathrm{N} \mathrm{NaOH})$. For the waterdispersible clay, the same granulometry procedure was applied without the use of $\mathrm{NaOH}$. The degree of clay dispersion (CD) was calculated by the ratio of waterdispersible clay to total clay.

A multiple linear regression model was fitted using the method of least squares and the data collected from the 46 areas ( 40 agricultural areas and 6 native forests). The model's normality was verified by the quantilequantile plot, and Shapiro-Wilk's test, at 5\% of probability. To negate the effect of the unit of variables, the regression metric coefficients were standardized according to the formula $\beta^{\prime} \mathrm{k}=\beta \mathrm{k} \times \mathrm{Sxk} / \mathrm{Sy}$, in which: $\beta^{\prime} \mathrm{k}$ is the normalized coefficient of the explanatory attribute $\mathrm{K} ; \beta \mathrm{k}$ is the metric coefficient of the explanatory attribute $\mathrm{K}$; Sxk is the standard deviation of the explanatory attribute K; and Sy is the standard deviation of the attribute response. Based on the standardized coefficients, the contributions of explanatory attributes were ranked and compared according to confidence intervals of $95 \%$.

Forty agricultural areas were sampled, and the CD was compared in the 29 most contrasting ones in relation to the management and to the IQP analyzed

Table 2. Weighting factors and formula for component indicators of the no-tillage system (NTS) participatory quality index (IQP), 2015, according to Nunes et al. (2020).

\begin{tabular}{|c|c|c|}
\hline Indicator & Weighting factor & Calculation \\
\hline Crop rotation intensity (RI) & 1.5 & Number of crops in 3 years $/ 9^{(1)}$ \\
\hline Crop rotation diversity $(\mathrm{RD})$ & 1.5 & Different vegetal species in the rotation/ $4^{(2)}$ \\
\hline Persistence of straw (PS) & 1.5 & Number of grasses in the rotation/ $6^{(3)}$ \\
\hline Soil-tillage frequency $(\mathrm{TF})$ & 1.5 & Years between tillage or (if no-tillage) base $\mathrm{x} 0.8^{(4)}$ \\
\hline \multirow[t]{3}{*}{ Correct terracing $(\mathrm{CT})$} & 1.0 & Overflow $<2, \mathrm{SC}=1.0$ \\
\hline & & $2<$ Overflow $<3, \mathrm{SC}=0.5$ \\
\hline & & Overflow $>3, \mathrm{SC}=0^{(5)}$ \\
\hline \multirow[t]{2}{*}{ Soil conservation evaluation (SC) } & 1.0 & If: Countour-line operations/ No erosion signals/ \\
\hline & & $\begin{array}{l}\text { No surround soil compaction/ No soil compaction, }+1 \text { for each. } \\
\qquad \sum / 4^{(6)}\end{array}$ \\
\hline Balanced soil fertilization (BF) & 1.0 & $\begin{array}{l}\text { If: if based on soil chemical analysis } \\
\text { (chemical fertilization/ liming, }+0.5 \text { for each) }^{(7)}\end{array}$ \\
\hline Producer's commitment (PC) & 1.0 & Years under NTS $/ 25^{(8)}$ \\
\hline
\end{tabular}

Pesq. agropec. bras., Brasília, v.55, e01279, 2020

DOI: 10.1590/S1678-3921.pab2020.v55.01279 
per watershed, at 5\% probability. The t-test (2 areas), Tukey's test ( 3 to 9 areas), and Scott-Knott's test ( $\geq 10$ areas compared) were used to compare the degree of dispersion. The IQP scores, CD grades, and TOC contents of the different farm systems and native forests contrasted by analysis of variance (Anova) with unbalanced data, and, the means were compared by Scott-Knott's test, at 5\% probability. All analyses were performed in the R software (R Core Team, 2018).

\section{Results and Discussion}

All evaluated areas have their soil with heavy clay, except for one area, which fits into a clay textural class (FAO, 1988). The values of clay varied from 585 to $832.5 \mathrm{~g} \mathrm{~kg}^{-1}$ (Figure 1), which is a relatively small variation that exists in the region, as a consequence of the homogeneity of the parent material (basalt, from Serra Geral formation). There is a significant difference for the degree of clay dispersion (CD) between the Sanga Mineira, Facão Torto, and Arroio Fundo, Ajuricaba and Curvado watersheds (AAC) (Table 3). There was a significant difference for CD in the two areas evaluated in the Sanga Mineira watershed between the no-tillage with crop succession (NT) and no-tillage with soil disturbance (NTD) farm systems. The area with NT showed the highest IQP, the

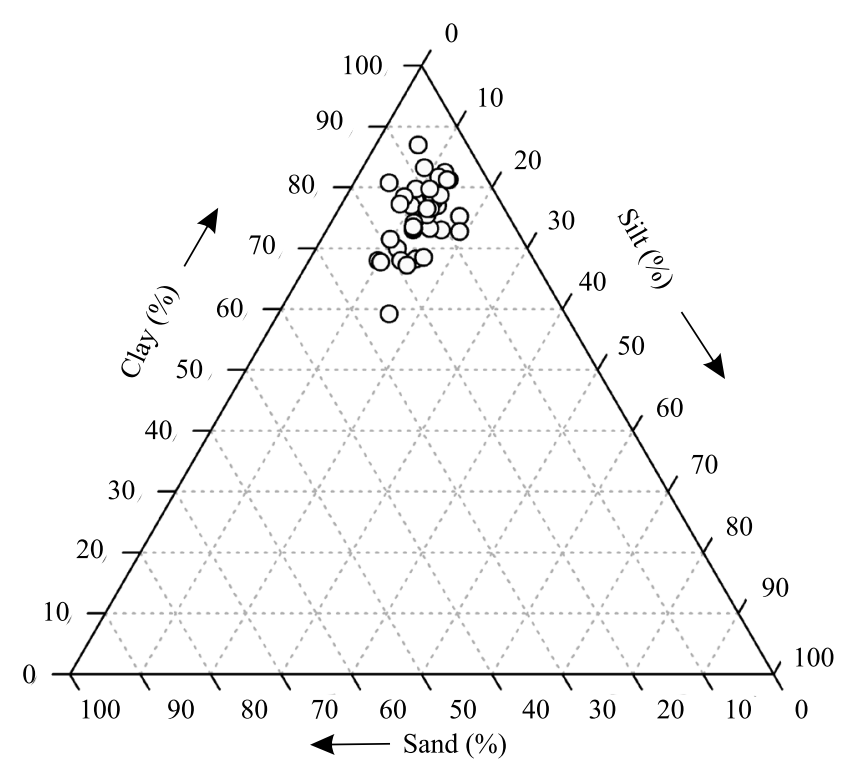

Figure 1. Textural triangle of the different evaluated areas from 0.0 to $0.20 \mathrm{~m}$ soil depth, in the West of Paraná state, Brazil, June and July, 2015. highest $\mathrm{CD}$ and $\mathrm{K}^{+}$, and even the lowest $\mathrm{Ca}^{2+}+\mathrm{Mg}^{2+}$. In contrast, the area with NTD had the lowest $\mathrm{CD}$ and $\mathrm{K}^{+}$ and the highest $\mathrm{Ca}^{2+}+\mathrm{Mg}^{2+}$ content.

The multiple linear regression model was applied, since $\mathrm{CD}$ phenomena is affected by many factors, such as the charge sparsity of the cations in the exchange complex (Melo et al., 2020), $\mathrm{pH}$, and point of zero charge (Chorom \& Rengasamy, 1995), organic matter content, mineralogy (Melo et al., 2019), and phosphate adsorption. The analyses by multiple regression evidenced that $\mathrm{TOC}, \mathrm{Ca}^{2+}+\mathrm{Mg}^{2+}$ and $\mathrm{H}+\mathrm{Al}^{3+}$ were negatively associated with $\mathrm{CD}$, while $\mathrm{K}^{+}$was positively associated with $\mathrm{CD}$. Phosphorus and $\mathrm{pH}$ associations with CD were not significant (Figure 2).

One area under NT and the area under CS in Facão Torto showed a significant difference regarding CD. The highest CD was observed in the area with CS, which showed the lowest IQP, besides the highest $\mathrm{H}+\mathrm{Al}^{3+}$ and the lowest $\mathrm{Ca}^{2+}+\mathrm{Mg}^{2+}$ and TOC levels. In contrast, the lowest $\mathrm{CD}$ was observed in the area with NT, which showed the highest IQP, $\mathrm{Ca}^{2+}+\mathrm{Mg}^{2+}$ and TOC, and the lowest $\mathrm{H}+\mathrm{Al}^{3+}$. Despite the low $\mathrm{H}+\mathrm{Al}^{3+}$ in the NT area $17, \mathrm{Ca}^{2+}$ and $\mathrm{Mg}^{2+}$ were high and probably enough to neutralize the particles' electric field. In highly weathered soils, $\mathrm{Ca}$ and $\mathrm{Mg}$ have similar capacity to induce clay flocculation, despite their distinct charge sparsity, probably because the charge density of kaolinite (the main clay mineral in these soils) is low, according to Melo et al. (2020). These authors also show that this fact does not necessarily happen in soils with predominance of clay minerals with high-charge density.

In the watersheds of Ajuricaba, Arroio Fundo, and Curvado (AAC), the highest $\mathrm{CD}$ in all the evaluated areas was observed in area 28 with NT, which showed 5.5 IQP and the lowest levels of TOC, $\mathrm{H}+\mathrm{Al}^{3+}$, and $\mathrm{Ca}^{2+}+\mathrm{Mg}^{2+}$ (Table 3). In areas 26 and 29 with $\mathrm{CS}$, higher $\mathrm{CD}$ values than in other $\mathrm{CS}$ areas were observed. However, area 26 shows lower levels of TOC, $\mathrm{Ca}^{2+}+\mathrm{Mg}^{2+}$, and $\mathrm{K}^{+}$than area 29. In this case, despite the highest content of flocculant cations in area $26\left(\mathrm{Ca}^{2+}+\mathrm{Mg}^{2+}\right)$, the $\mathrm{K}^{+}$content was higher than the area 20. Consequently, it was not possible to verify difference for $\mathrm{CD}$ between these areas.

The lowest $\mathrm{CD}$ of watershed $\mathrm{AAC}$ was verified in area 20, with NT and with the highest values of IQP and $\mathrm{H}+\mathrm{Al}^{3+}$, besides the lowest $\mathrm{K}^{+}$content, which corroborates Nguetnkam \& Dultz (2014), since these 
ions are considered as the main flocculating agents in the soil (Basga et al., 2018). $\mathrm{H}^{+}$is a potential- determining ion and, consequently, it can favor the balance of charges in these soils, which results in

Table 3. No-tillage system participatory quality index (IQP), the degree of clay dispersion (CD), and soil chemical composition of the 29 evaluated areas and native forests (NF) of the different farm systems (FS), at $0.0-0.20 \mathrm{~m}$ soil depth, in the West of Paraná state, Brazil, June and July, 2015 ${ }^{(1)}$.

\begin{tabular}{|c|c|c|c|c|c|c|c|c|c|c|}
\hline \multirow[t]{2}{*}{ Watershed } & \multirow[t]{2}{*}{ Area } & \multirow[t]{2}{*}{$\mathrm{FS}^{(2)}$} & \multirow[t]{2}{*}{$\mathrm{IQP}^{*}$} & \multirow{2}{*}{$\begin{array}{c}\mathrm{CD} \\
\% \\
\end{array}$} & \multirow{2}{*}{$\frac{\text { TOC }}{\left(\mathrm{g} \mathrm{kg}^{-1}\right)}$} & \multirow[t]{2}{*}{$\mathrm{pH}$} & $\mathrm{H}+\mathrm{Al}^{3+}$ & $\mathrm{Ca}^{2+}+\mathrm{Mg}^{2+}$ & $\mathrm{K}^{+}$ & $\mathrm{P}$ \\
\hline & & & & & & & \multicolumn{4}{|c|}{$\left(\mathrm{cmol}_{\mathrm{c}} \mathrm{dm}^{3}\right)$} \\
\hline \multirow{3}{*}{ Sanga Mineira } & 1 & NT & 7.9 & $87 a$ & $11.96 \mathrm{a}$ & $5.3 \mathrm{a}$ & $3.65 \mathrm{a}$ & $9.47 \mathrm{~b}$ & $0.64 \mathrm{a}$ & $7.48 \mathrm{a}$ \\
\hline & 2 & NTD & 7.5 & $73 b$ & $11.18 \mathrm{a}$ & $5.6 \mathrm{a}$ & $3.24 \mathrm{a}$ & $11.39 \mathrm{a}$ & $0.27 \mathrm{~b}$ & $4.99 \mathrm{a}$ \\
\hline & & $\mathrm{NF}$ & & 78 & 22.04 & 5.9 & 2.98 & 12.22 & 0.60 & 2.69 \\
\hline \multirow{8}{*}{ Toledo } & 3 & NT & 5.3 & $79 a$ & $15.11 \mathrm{a}$ & $5.6 \mathrm{a}$ & $3.86 \mathrm{~b}$ & $7.41 \mathrm{~b}$ & $0.50 \mathrm{a}$ & $19.66 \mathrm{a}$ \\
\hline & 4 & NTS & 8.1 & $78 \mathrm{a}$ & $18.73 \mathrm{a}$ & $5.3 b$ & $5.14 \mathrm{a}$ & $7.34 \mathrm{~b}$ & $0.48 \mathrm{a}$ & $9.30 \mathrm{a}$ \\
\hline & 5 & NT & 8.9 & $72 \mathrm{a}$ & $17.00 \mathrm{a}$ & $5.7 \mathrm{a}$ & $3.70 \mathrm{~b}$ & $7.97 \mathrm{a}$ & $0.44 \mathrm{a}$ & $22.22 \mathrm{a}$ \\
\hline & 6 & NT & 8.6 & $84 a$ & $18.73 \mathrm{a}$ & $5.2 \mathrm{~b}$ & $5.48 \mathrm{a}$ & $7.26 \mathrm{~b}$ & $0.45 \mathrm{a}$ & $8.31 \mathrm{a}$ \\
\hline & 7 & NT & 8.9 & $77 \mathrm{a}$ & $12.59 \mathrm{a}$ & $5.0 \mathrm{~b}$ & $4.72 \mathrm{a}$ & $5.85 b$ & $0.51 \mathrm{a}$ & $18.72 \mathrm{a}$ \\
\hline & 8 & NT & 7.6 & $78 \mathrm{a}$ & $14.48 \mathrm{a}$ & $4.7 \mathrm{~b}$ & $6.22 \mathrm{a}$ & $4.81 \mathrm{~b}$ & $0.37 \mathrm{a}$ & $18.64 \mathrm{a}$ \\
\hline & 9 & NT & 7.8 & $73 a$ & $17.63 \mathrm{a}$ & $5.2 \mathrm{~b}$ & $5.35 \mathrm{a}$ & $8.14 \mathrm{a}$ & $0.53 \mathrm{a}$ & $22.15 \mathrm{a}$ \\
\hline & & NF & & 53 & 25.34 & 4.3 & 1.69 & 6.93 & 0.18 & 2.39 \\
\hline \multirow{4}{*}{ Buriti } & 10 & NTD & 8.3 & $86 a$ & $9.60 \mathrm{~b}$ & $5.1 \mathrm{a}$ & $3.97 \mathrm{a}$ & $7.80 \mathrm{a}$ & $0.60 \mathrm{a}$ & $16.28 \mathrm{a}$ \\
\hline & 11 & NT & 7.4 & $79 a$ & $14.64 a b$ & $5.2 \mathrm{a}$ & $4.43 \mathrm{a}$ & $7.83 a$ & $0.76 \mathrm{a}$ & $23.05 \mathrm{a}$ \\
\hline & 12 & NTS & 8.4 & $77 \mathrm{a}$ & $19.05 \mathrm{a}$ & $5.4 \mathrm{a}$ & $3.44 \mathrm{a}$ & $8.37 \mathrm{a}$ & $0.74 a$ & $12.48 \mathrm{a}$ \\
\hline & & $\mathrm{NF}$ & & 81 & 14.43 & 5.2 & 3.95 & 8.00 & 0.70 & 17.27 \\
\hline \multirow{4}{*}{ Pacuri } & 13 & NT & 7.0 & $80 \mathrm{a}$ & $10.86 \mathrm{a}$ & $5.3 \mathrm{a}$ & $3.92 \mathrm{a}$ & $8.30 \mathrm{a}$ & $0.57 \mathrm{a}$ & $26.87 \mathrm{a}$ \\
\hline & 14 & NT & 8.5 & $85 \mathrm{a}$ & $13.06 \mathrm{a}$ & $5.1 \mathrm{a}$ & $4.28 \mathrm{a}$ & $8.25 \mathrm{a}$ & $0.65 \mathrm{a}$ & $9.16 \mathrm{a}$ \\
\hline & 15 & NTD & 7.3 & $82 \mathrm{a}$ & $10.39 \mathrm{a}$ & $5.0 \mathrm{a}$ & $4.68 \mathrm{a}$ & $7.39 \mathrm{a}$ & $0.41 \mathrm{a}$ & $23.24 \mathrm{a}$ \\
\hline & & $\mathrm{NF}$ & & 82 & 11.96 & 5.2 & 4.30 & 7.82 & 0.61 & 18.02 \\
\hline \multirow{5}{*}{ Facão Torto } & 16 & NT & 6.7 & $80 \mathrm{ab}$ & $11.49 \mathrm{ab}$ & $5.4 \mathrm{a}$ & $3.64 b$ & $8.47 \mathrm{~b}$ & $0.61 \mathrm{a}$ & $12.00 \mathrm{a}$ \\
\hline & 17 & NT & 6.9 & $78 \mathrm{~b}$ & $15.11 \mathrm{a}$ & $6.1 \mathrm{a}$ & $2.81 \mathrm{~b}$ & $10.68 \mathrm{a}$ & $0.71 \mathrm{a}$ & $25.97 \mathrm{a}$ \\
\hline & 18 & CS & 4.1 & $88 \mathrm{a}$ & $9.13 b$ & $4.6 \mathrm{~b}$ & $6.14 a$ & $6.00 \mathrm{c}$ & $0.76 \mathrm{a}$ & $26.39 a$ \\
\hline & 19 & NT & 6.1 & $84 \mathrm{ab}$ & $10.07 \mathrm{ab}$ & $5.5 \mathrm{a}$ & $3.23 b$ & $7.75 b$ & $0.58 \mathrm{a}$ & $18.79 a$ \\
\hline & & $\mathrm{NF}$ & & 82 & 11.45 & 5.4 & 3.96 & 8.23 & 0.66 & 20.79 \\
\hline \multirow{11}{*}{$\begin{array}{l}\text { Arroio Fundo, } \\
\text { Ajuricaba, and } \\
\text { Curvado (AAC) }\end{array}$} & 20 & NT & 7.8 & $65 \mathrm{~d}$ & $16.84 \mathrm{a}$ & $4.6 \mathrm{c}$ & $6.40 \mathrm{~b}$ & $6.82 \mathrm{e}$ & $0.24 d$ & $25.42 \mathrm{a}$ \\
\hline & 21 & NT & 7.6 & $78 \mathrm{~b}$ & $14.17 \mathrm{a}$ & $5.3 b$ & $3.88 \mathrm{c}$ & $10.25 b$ & $0.43 c$ & $5.30 \mathrm{~b}$ \\
\hline & 22 & NT & 5.8 & $70 \mathrm{~d}$ & $13.85 \mathrm{a}$ & $5.3 b$ & $4.11 \mathrm{c}$ & $9.71 \mathrm{~b}$ & $0.51 \mathrm{c}$ & $5.63 b$ \\
\hline & 23 & NT & 4.4 & $78 \mathrm{~b}$ & $12.91 \mathrm{a}$ & $4.6 \mathrm{c}$ & $4.71 \mathrm{c}$ & $6.06 \mathrm{e}$ & $0.51 \mathrm{c}$ & $8.54 \mathrm{~b}$ \\
\hline & 24 & NT & 7.0 & $73 c$ & $11.18 \mathrm{~b}$ & $4.0 \mathrm{~d}$ & $8.84 \mathrm{a}$ & $6.15 \mathrm{e}$ & $0.54 \mathrm{c}$ & $33.61 \mathrm{a}$ \\
\hline & 25 & NTD & 7.1 & $84 a$ & $14.01 \mathrm{a}$ & $5.5 \mathrm{~b}$ & $3.64 \mathrm{c}$ & $8.43 \mathrm{c}$ & $0.96 \mathrm{a}$ & $21.97 \mathrm{a}$ \\
\hline & 26 & $\mathrm{CS}$ & 5.7 & $82 \mathrm{a}$ & $9.44 \mathrm{~b}$ & $4.9 \mathrm{c}$ & $4.42 \mathrm{c}$ & $8.09 \mathrm{c}$ & $0.08 \mathrm{~d}$ & $2.75 b$ \\
\hline & 27 & NTS & 6.3 & $76 c$ & $15.58 \mathrm{a}$ & $5.2 \mathrm{~b}$ & $3.88 \mathrm{c}$ & $9.14 b$ & $0.47 \mathrm{c}$ & $28.82 \mathrm{a}$ \\
\hline & 28 & NT & 5.5 & $89 a$ & $12.43 \mathrm{~b}$ & $5.2 \mathrm{~b}$ & $3.74 \mathrm{c}$ & $7.75 \mathrm{~d}$ & $0.37 \mathrm{c}$ & $14.75 b$ \\
\hline & 29 & $\mathrm{CS}$ & 4.7 & $83 a$ & $15.11 \mathrm{a}$ & $5.9 \mathrm{a}$ & $3.23 \mathrm{c}$ & $17.23 \mathrm{a}$ & $0.68 \mathrm{~b}$ & $2.97 \mathrm{~b}$ \\
\hline & & $\mathrm{NF}$ & & 77 & 13.59 & 5.1 & 4.69 & 8.96 & 0.48 & 14.97 \\
\hline
\end{tabular}

(1)Means followed by equal letters, in the columns, do not differ by the t-test (Sanga Mineira), Tukey's test (Toledo, Buriti, Pacuri, and Facão Torto), and Scott-Knott's test (AAC), at 5\% probability. ${ }^{(2)}$ NTS, no-tillage system; NT, no-tillage with crop succession; NTD, no-tillage with soil disturbance; and CS, conventional system. 
higher-clay flocculation (Melo et al., 2020). As a trivalent cation, $\mathrm{Al}^{3+}$ enables the thickness reduction of the double electric layer of soil clay, decreasing the electrostatic repulsion of the particles (Chaves et al., 2001). Our results corroborate those reported by Igwe \& Udegbunam (2008), who found that $\mathrm{Ca}^{2+}$ and $\mathrm{H}+\mathrm{Al}^{3+}$ were the factors that most influenced CD (Figure 2). Despite the reduction of clay dispersion, high levels of potential acidity and $\mathrm{Al}^{3+}$ are considered negative for nutrient availability and root development in the soil and should be neutralized. Therefore, chemical correction should be adequately planned, especially for the dose to be applied.

In the analyses of the 40 areas, a positive correlation between $\mathrm{CD}$ and $\mathrm{K}^{+}$, and a negative one with $\mathrm{Ca}^{2+}+\mathrm{Mg}^{2+}$, $\mathrm{H}+\mathrm{Al}^{3+}$, and TOC $(\mathrm{p} \leq 0.05)$ were observed (Figure 2). These results explain the obtained ones from $\mathrm{CD}$ for $\mathrm{NF}$, which were close to or even above to those of some agricultural areas, a fact that hinders its adoption as an isolated conclusive indicator. The $\mathrm{Ca}^{2+}+\mathrm{Mg}^{2+}$ contents were the most influential factors in the reduction of $\mathrm{CD}$, followed by $\mathrm{H}+\mathrm{Al}^{3+}$ and TOC. $\mathrm{K}^{+}$is the factor that contributed most to the increase of $\mathrm{CD}$. Phosphorus and $\mathrm{pH}$ did not contribute statistically with $\mathrm{CD}$. In the watersheds assessed in the present study, the lowest $\mathrm{CD}$ values were verified in the areas with the highest levels of $\mathrm{Ca}^{2+}+\mathrm{Mg}^{2+}$ and TOC, except for the AAC watershed. In this watershed, the lowest value of $C D$ was observed in the area with the highest-TOC content.

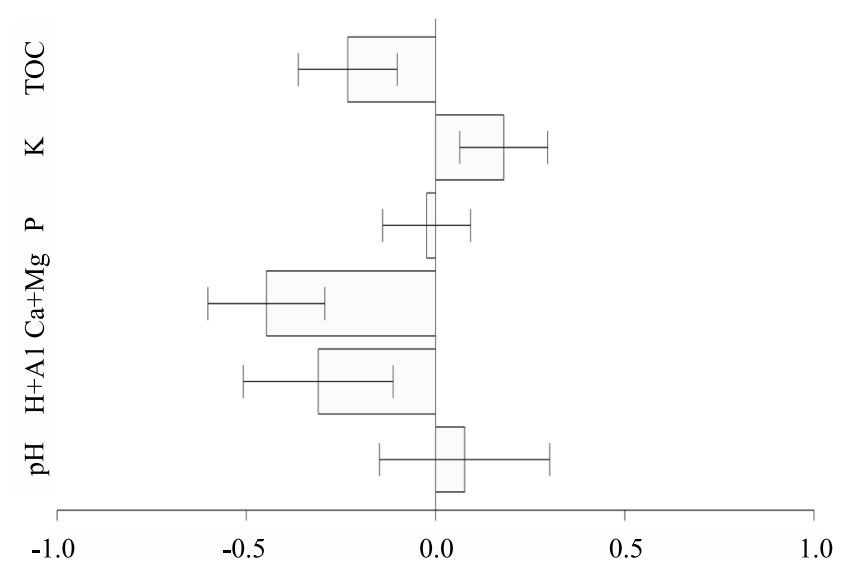

Figure 2. Standardized coefficients (axis x) of soil chemical properties for the degree of clay dispersion in 46 areas (40 farm systems and 6 native forests), in the West of Paraná state, Brazil, June and July, 2015.
Farm systems with the highest-TOC contents show the lowest values of $\mathrm{CD}$, once organic matter (OM) contributes significantly to soil aggregation (Basga et al., 2018).

Farm systems with the highest levels of $\mathrm{K}^{+}$showed the highest CD (Figure 2), which corroborates the observations by Nguetnkam \& Dultz (2014), as verified in the present work in Sanga Mineira and AAC for the similarity found in watersheds with the same $\mathrm{K}^{+}$content (Toledo, Buriti, and Pacuri). Spera et al. (2008) state that the thickness of the double electric layer is altered by the cation concentration and nature. Low-valence cations such as $\mathrm{Na}^{+}$and $\mathrm{K}^{+}$have a low capacity to neutralize the electric field generated by the particles, which intensifies the repulsive forces and facilitates dispersion. The increase of $\mathrm{CD}$ as a function of the higher levels of $\mathrm{K}^{+}$shows its deleterious effect on the soil structure - a fact that has received little attention (Paradelo et al., 2013).

The clay dispersion was similar for all farm systems (Table 4). Nonetheless, the lowest-IQP score was verified in CS, which proves the sensitivity of IQP to assess the quality of management (Nunes et al., 2020). A greater TOC content was observed in NTS and in native forests than in the other systems with farm management that underwent more disturbance. The OM is directly related to carbon stock and nutrient availability, soil structure maintenance and the microbiological activity (Martinez-Salgado et al., 2010). Higher levels of $\mathrm{OM}$ and $\mathrm{Ca}^{2+}$, along with the presence of other cations in the soil promote the

Table 4. No-tillage system participatory quality index (IQP), degree of clay dispersion (CD), and total organic carbon (TOC) in the different farm systems and native forests, at $0.0-0.20 \mathrm{~m}$ soil depth, in the West of the Paraná state, Brazil, June and July, 2015(1).

\begin{tabular}{lccc}
\hline Farm system & IQP & $\begin{array}{c}\text { CD } \\
(\%)\end{array}$ & $\begin{array}{c}\text { TOC } \\
\left(\mathrm{g} \mathrm{kg}^{-1}\right)\end{array}$ \\
\hline No-tillage system (NTS) & $7.60 \mathrm{a}$ & 77.00 & $17.79 \mathrm{a}$ \\
No-tillage with crop succession (NT) & $7.14 \mathrm{a}$ & 78.37 & $13.90 \mathrm{~b}$ \\
No-tillage with soil disturbance (NTD) & $7.55 \mathrm{a}$ & 81.25 & $11.30 \mathrm{~b}$ \\
Conventional system (CS) & $4.83 \mathrm{~b}$ & 84.33 & $11.23 \mathrm{~b}$ \\
Native forest (NF) & - & 75.50 & $16.47 \mathrm{a}$ \\
\hline CV (\%) & 18.2 & 8.7 & 22.9 \\
\hline
\end{tabular}

${ }^{(1)}$ Means followed by equal letters, in the columns, do not differ from each other by Scott-Knott's test, at $5 \%$ probability. ${ }^{(2)} \mathrm{IQP}$ is an index to evaluate farm systems, and it is not applicable to native areas. 
flocculation and aggregation of negatively charged clay particles (Tavares Filho et al., 2010).

Matias et al. (2012) state that the soil management causes changes in $\mathrm{OM}$ and soil physical properties. The incorporation of plant residues increases the clay dispersion (Igwe \& Udegbunam, 2008), in comparison to the residues left on the soil, as it affects the dynamics of the OM, reducing the aggregation of the soil. Cardoso et al. (2013) state that the acceleration of the oxidation and reduction of stable OM reduces the biological activity. OM made it possible to monitor the changes of management quality and, consequently, of soil quality, which corroborates the findings of Shukla et al. (2006).

In our study, the CS and NTD evaluated areas had their conditions aggravated by soil disturbance, which results from their lower-TOC contents. The lowestTOC content may be attributed to the low level of $\mathrm{OM}$ entering in the farm systems, as observed in the no-tillage with crop succession and in conventional systems in the Buriti, Facão Torto, and AAC watersheds.

In general, the soil chemical management was more important for the $\mathrm{CD}$ changes than soil plowing. This finding can be inferred from the high number of significant associations between $\mathrm{CD}$ and soil chemical properties (Figure 2), and from the small number of statistical differences between NT and CT areas (Table 3). However, the mechanical effect from the soil disturbance had less influence than the chemical management, as it can be observed in the Sanga Mineira watershed. The mechanical effect is manifested mainly by the intense disturbance of the soil, as in the conventional system in the Facão Torto watershed. However, areas under NTS showed the greatest TOC content, the main factor for nutrient availability, soil structure maintenance, and soil health sustainability (Cardoso et al., 2013). The aggregation results from the rearrangement, flocculation, and cementation of particles by inorganic and organic substances (Bronick \& Lal, 2005). Aggregation is affected by OM due to the nature of the cations present in the soil and their charge sparsity (Melo et al., 2020), as well as to the interaction of polyvalent cations with humic OM and clay, soil mineralogy, the presence of organic acids, and the behavior of aluminum, depending on the $\mathrm{pH}$ of the soil solution (Rengasamy, 2018).
Therefore, the negative mechanical effect of the soil disturbance on the clay dispersion can be partially neutralized by the chemical management of the soil and the adequate fertilization of the production system. However, Melo et al. (2019) have shown that the reduction of $\mathrm{CD}$ does not imply necessarily that soil structural stability was improved. Floccules formed by electrostatic attraction are ephemerous and can be easily disrupted.

It was possible to verify the OM importance by the similarity between the NTS and NF, reflected in their greatest IQP score and lowest CD among the farm systems assessed. In order to ensure the agricultural sustainability, conservation practices should be prioritized to increase and maintain the $\mathrm{OM}$ and a minimum soil disturbance. As an essential component of soil fertility, OM contributes positively to soil chemical, physical, and biological properties, improving the productivity and quality of production systems (Kaschuk et al., 2010).

The soil chemical properties had a greater influence on the $\mathrm{CD}$ than on the quality of the soil management system assessed by IQP, since, in fact, the intensive soil use interferes negatively with the soil chemical properties. Nevertheless, the effects of farm systems are more complex, depending on several factors. Even so, chemical management requires as much attention as soil tillage and crop rotation systems. Therefore, all factors capable to interfere with clay dispersion should be monitored because the greater the $\mathrm{CD}$, the greater the risks of erosion and compaction processes, causing damage to soil quality and agricultural sustainability. In addition, it has been endorsed that the NTS, when fully adopted, can mitigate the negative impact of management on soil quality, making the system more balanced and sustainable (Cardoso et al., 2013).

\section{Conclusions}

1. The soil chemical properties have a greater influence on the clay dispersion than the different farm systems assessed.

2. No-tillage system used in full shows the highest organic carbon content, which is similar to that of the evaluated native areas.

3. The areas managed with conventional system and no-tillage with soil disturbance show the highest levels of clay dispersion and the lowest no-tillage system 
participatory quality index (IQP), in relation to the areas with no-tillage system used in full.

4. The IQP was effective to distinguish the conventional system from the no-tillage system; this index agreed with extreme values of clay dispersion and total organic carbon; therefore, this tool can help farmers to monitor the management quality of their agricultural areas.

\section{Acknowledgments}

To Conselho Nacional de Desenvolvimento Científico e Tecnológico (CNPq), for financial support (Edital Universal 461484/2014); to Coordenação de Aperfeiçoamento de Pessoal de Nível Superior (Capes), for support, and master and doctoral scholarships (Finance code 001) to the first author; to Federação Brasileira de Plantio Direto e Irrigação (FEBRAPDP), Itaipu Binacional, and Parque Tecnológico Itaipu, for permitting the use of facilities that provided the conditions for this research; to the farmers, for the permission to obtain soil data from their properties; to the field team composed by Ana Carolina Polinarski Coqueiro, Tatiane Gorte, Caroline Laurini Tonetti, Alessandra Santos, Guilherme Cardoso, and Herlon Nadolny, who made this work possible.

\section{References}

BARTZ, M.L.C.; PASINI, A.; BROWN, G.G. Earthworms as soil quality indicators in Brazilian no-tillage systems. Applied Soil Ecology, v.69, p.39-48, 2013. DOI: https://doi.org/10.1016/j. apsoil.2013.01.011

BASGA, S.D.; TSOZUE, D.; TEMGA, J.P.; BALNA, J.; NGUETNKAM, J.P. Land use impact on clay dispersion/ flocculation in irrigated and flooded vertisols from Northern Cameroon. International Soil and Water Conservation Research, v.6, p.237-244, 2018. DOI: https://doi.org/10.1016/j. iswer.2018.03.004.

BRONICK, C.J.; LAL, R. Soil structure and management: A review. Geoderma, v.124, p.3-22, 2005. DOI: https://doi.org/10.1016/j.geoderma.2004.03.005.

CARDOSO, E.J.B.N.; VASCONCELLOS, R.L.F.; BINI, D.; MIYAUCHI, M.Y.H.; SANTOS, C.A. dos; ALVES, P.R.L.; PAULA, A.M. de; NAKATANI, A.S.; PEREIRA, J. de M.; NOGUEIRA, M.A. Soil health: looking for suitable indicators. What should be considered to assess the effects of use and management on soil health? Scientia Agricola, v.70, p.274-289, 2013. DOI: https://doi.org/10.1590/S0103-90162013000400009.

CHAVES, L.H.G.; CHAVES, I. de B.; LUNA, J.G. Alteração na taxa de percolação de um Neossolo Flúvico tratado com sulfatos de cálcio e alumínio e carbonato de cálcio. Agropecuária Técnica, v.22, p.13-19, 2001.

CHOROM, M.; RENGASAMY, P. Dispersion and zeta potential of pure clays as related to net particle charge under varying $\mathrm{pH}$, electrolyte concentration and cation type. European Journal of Soil Science, v.46, p.657-665, 1995. DOI: https://doi.org/10.1111/j.1365-2389.1995.tb01362.x.

CLAESSEN, M.E.C. (Org.). Manual de métodos de análise de solo. 2.ed. rev. e atual. Rio de Janeiro: Embrapa-CNPS, 1997. 212p. (Embrapa-CNPS. Documentos, 1).

DEMARCHI, J.C.;ZIMBACK, C.R.L. Mapeamento, erodibilidade e tolerância de perda de solo na sub-bacia do Ribeirão das Perobas. Energia na Agricultura, v.29, p.102-114, 2014. DOI: https://doi.org/10.17224/EnergAgric.2014v29n2p102-114.

FAO. FAO/UNESCO soil map of the world: revised legend. Rome: FAO, 1988. (World Soil Resources Report, 60). Available at: $<$ https://www.isric.org/sites/default/files/isric_report_1988_01. pdf $>$. Accessed on: May 272020.

IGWE, C.A.; OBALUM, S.E. Microaggregate stability of tropical soils and its role on soil erosion hazard prediction. In: GRUNDAS, S.; STEPNIEWSKI, A. (Ed.). Advances in Agrophysical Research. London: Intechopen, 2013. p.175-192. DOI: https://doi.org/10.5772/52473.

IGWE, C.A.; UDEGBUNAM, O.N. Soil properties influencing water-dispersible clay and silt in an Ultisol in southern Nigeria. International Agrophysics, v.22, p.319-325, 2008.

KASCHUK, G.; ALBERTON, O; HUNGRIA, M. Three decades of soil microbial biomass studies in Brazilian ecosystems: lessons learned about soil quality and indications for improving sustainability. Soil Biology \& Biochemistry, v.42, p.1-13, 2010. DOI: https://doi.org/10.1016/j.soilbio.2009.08.020.

MARTIN, M.; STANCHI, S.; HOSSAIN, K.M.J.; HUQ, S.M.I.; BARBERIS, E. Potential phosphorous and arsenic mobilization from Bangladesh soils by particle dispersion. Science of the Total Environment, v.536, p.973-980, 2015. DOI: https://doi.org/10.1016/j.scitotenv.2015.06.008.

MARTINEZ-SALGADO, M.M.; GUTIÉRREZ-ROMERO, V.; JANNSENS, M.; ORTEGA-BLU, R. Biological soil quality indicators: a review. In: MÉNDEZ-VILAS, A. (Ed.). Current Research, Technology and Education topics in Applied Microbiology and Microbial Biotechnology. Badajoz: Formatex, 2010. p.319-328.

MATIAS, S.S.R.; CORREIA, M.A.R.; CAMARGO, L.A.; FARIAS, M.T. de; CENTURION, J.F.; NÓBREGA, J.C.A. Influência de diferentes sistemas de cultivo nos atributos físicos e no carbono orgânico do solo. Revista Brasileira de Ciências Agrárias, v.7, p.414-420, 2012. DOI: https://doi.org/10.5039/ agraria.v7i3a1462.

MELO, T.R. de; MACHADO, W.; TAVARES FILHO, J. Charge sparsity: an index to quantify cation effects on clay dispersion in soils. Scientia Agricola, v.77, e20170392, 2020. DOI: https://doi.org/10.1590/1678-992x-2017-0392.

MELO, T.R. de; RENGASAMY, P.; FIGUEIREDO, A.; BARBOSA, G.M. de C.; TAVARES FILHO, J. A new approach on 
the structural stability of soils: method proposal. Soil \& Tillage Research, v.193, p.171-179, 2019. DOI: https://doi.org/10.1016/j. still.2019.04.013.

METODOLOGIA participativa para avaliar a qualidade do plantio direto na bacia hidrográfica Paraná III. Ponta Grossa: FEBRAPDP, 2011. 99p. Available at: <https://febrapdp.org.br/ download/publicacoes/Metodologia_comp.pdf $\geq$._Accessed on: May 272020.

NGUETNKAM, J.P.; DULTZ, S. Clay dispersion in typical soils of North Cameroon as a function of $\mathrm{pH}$ and electrolyte concentration. Land Degradation Development, v.25, p.153-162, 2014. DOI: https://doi.org/10.1002/ldr.1155.

NUNES, A.L.P.; BARTZ, M.L.; MELLO, I.; BORTOLUZZI, J.; ROLOFF, G.; FUENTES LLANILLO, R.; CANALLI, L.; WANDSCHEER, C.A.R.; RALISCH, R. No-till system participatory quality index in land management quality assessment in Brazil. European Journal of Soil Science, p.1-14, 2020. DOI: https://doi.org/10.1111/ejss.12943.

PARADELO, R.; VAN OORT, F.; CHENU, C. Waterdispersible clay in bare fallow soils after 80 years of continuous fertilizer addition. Geoderma, v.200-201, p.40-44, 2013. DOI: https://doi.org/10.1016/j.geoderma.2013.01.014.

R CORE TEAM. R: a language and environment for statistical computing. Vienna: R Foundation for Statistical Computing, 2018. Available at: <https://www.R-project.org/>. Accessed on: May 272020.

RENGASAMY, P. Irrigation water quality and soil structural stability: A perspective with some new insights. Agronomy, v.8, art. 72, 2018. DOI: https://doi.org/10.3390/agronomy8050072.

ROLOFF, G.; LUTZ, R.A.T.; MELLO, I. Índice de qualidade participativo do plantio direto. Ponta Grossa: FEBRAPDP, 2011. 26p. (Boletim Técnico).

SANTOS, H.G. dos; JACOMINE, P.K.T.; ANJOS, L.H.C. dos; OLIVEIRA, V.A. de; LUMBRERAS, J.F.; COELHO, M.R.; ALMEIDA, J.A. de; CUNHA, T.J.F.; OLIVEIRA, J.B. de.
Sistema brasileiro de classificação de solos. 3.ed. rev. e ampl. Brasília: Embrapa, 2013. 353p.

SHUKLA, M.K.; LAL, R.; EBINGER, M. Determining soil quality indicators by factor analysis. Soil \& Tillage Research, v.87, p.194-204, 2006. DOI: https://doi.org/10.1016/j.still.2005.03.011.

SILVA, A.P. da; BABUJIA, L.C.; FRANCHINI, J.C.; RALISCH, R.; HUNGRIA, M.; GUIMARÃES, M. de F. Soil structure and its influence on microbial biomass in different soil and crop management systems. Soil \& Tillage Research, v.142, p.42-53, 2014. DOI: https://doi.org/10.1016/j.still.2014.04.006.

SILVA, D.C. da; SILVA, M.L.N.; CURI, N.; OLIVEIRA, A.H.; SOUZA, F.S. de; MARTINS, S.G.; MACEDO, R.L.G. Atributos do solo em sistemas agroflorestais, cultivo convencional e floresta nativa. Revista de Estudos Ambientais, v.13, p.77-86, 2011.

SOIL SURVEY STAFF. Keys to soil taxonomy. $12^{\text {th }}$ ed. Washington: USDA, 2014.

SPERA, S.T.; DENARDIM, J.E.; ESCOSTEGUY, P.A.V.; SANTOS, H.P. dos; FIGUEROA, E.A. Dispersão de argila em microagregados de solo incubado com calcário. Revista Brasileira de Ciência do Solo, v.32, p.2613-2620, 2008. Número especial. DOI: https://doi.org/10.1590/S0100-06832008000700002.

TAVARES FILHO, J.; BARBOSA, G.M. de C.; RIBON, A.A. Water-dispersible clay in soils treated with sewage sludge. Revista Brasileira de Ciência do Solo, v.34, p.1527-1534, 2010. DOI: https://doi.org/10.1590/S0100-06832010000500005.

TEDESCO, M.J.; GIANELLO, C.; BISSANI, C.A.; BOHEN, H.; VOLKWEISS, S.J. Análise de solo, plantas e outros materiais. 2.ed. rev. e ampl. Porto Alegre: UFGRS, 1995. 174p. (UFRGS. Boletim técnico, 5).

WALKLEY, A.; BLACK, I.A. An examination of the Degtjareff method for determining soil organic matter, and a proposed modification of the chromic acid titration method. Soil Science, v.37, p.29-38, 1934. DOI: https://doi.org/10.1097/00010694193401000-00003. 